\title{
THE POTENTIAL ROLE OF SOME PLANT EXTRACTS OF ANTIFUNGAL PROPERTIES AGAINST THE EFFICACY OF Trichoderma viride FOR CONTROLLING GRAY MOLD OF ONION CAUSED BY Botrytis cinerea
}

EI-Gali, Z. I.; N. A. Mohamed and A. A. Larbud

Dept. of Plant Protection, Fac. of Agric., Omer Al-Mukhtar Univ.EIBeida, P.O. 919.

Email: Z_Elgali@yahoo.com

\begin{abstract}
Botrytis cinerea Pers.; Fr., induces grey mold of onion worldwide. Fungicide applications are often used to control this pathogen. Natural plant extract do not show hazardous effects and likely to be used instead of the synthetic fungicides. In this study, antifungal activity of $5,10,20$ and $40 \mu \mathrm{L}$ of Mentha longifolia, Origanum marjoram, Artemisia sp and Trichoderma filtrate, respectively were applied in vitro to study their effect on the mycelial growth of $B$. cinerea using a poisoned food method. All treatments significantly presented their effect on the mycelia growth of the pathogen while the maximum inhibitory effect was shown when $40 \mu \mathrm{L}$ of the extract was used. The inhibitory effect was affected by the amounts of the extract and the incubation time of the samples. Samples treatment of $40 \mu \mathrm{L}$ concentration showed a maximum inhibition in the mycelia growth 5 days after incubation. This study shows that Artemisia sp has a potential to be used in the controlling management of $B$. cinerea. According to the available literature, this study could be the first to record the potential of Mentha longifolia, Origanum marjoram, Artemisia sp extracts and Trichoderma filtrate on the control of Botrytis cinerea, the causal agent of gray mold of onion in El-Beida, Libya.

Keywords: Onion, gray mold, antifungal activity, plant extracts, antagonistic fungi, Botrytis cinerea.
\end{abstract}

\section{INTRODUCTION}

Botrytis cinerea Pers.;Fr., is an aggressive pathogen attacks more than 200 plant species in the field (Coly-Smith, et al., 1980), greenhouse (Eden, et al., 1996; Sirjusingh, et al., 1996) and storage (Reyes, 1990; ELAbd, 2002). The successive use of pesticides for controlling pest has caused many problems to the ecosystem. So far, a reduced pesticide usage is needed in the agricultural regime in the present era.

New strategies in the control of fungal contamination have been investigated. One of these is the use of biocontrol agents including bacteria (Ketterer, et al., 1992), yeasts (Droby, et al., 1997), or antagonistic fungi (Eden, et al., 1996), essential oils (Sun, et al., 2007), plant extracts (Soylu, et al., 2005). The presence of antifungal compounds, in higher plants, has long been recognized as important factors in disease resistance. Such compounds, being biodegradable and selective in their toxicity, are 
considered valuable for controlling some plant diseases (Siva et al., 2008). In addition, plant extracts might have inhibitors to enzymes produced by the invading pathogens. The effects of different phenolic compounds found in many plants have inhibitory effects on the germination and growth of many fungal pathogens (Staub, 1991). Ramos et al. (2007) reported that components of Neem tree (Azadirachta indica) control Crinipellis perniciosa and Phytophthora species. Ocimum extracts which is used in traditional medicine contains active constituents of insecticidal, nematicidal, fungicidal and antimicrobial effect (Morales and Simon, 1996). Based on the above information, the objective of this study was carried out to investigate the effect of three plant extracts i.e.: Artemisia, Mint, Oregano and versus the antagonistic fungus Trichoderma viride on the growth of $B$. cinerea the causal agent of gray mold on onion bulbs in El-Beida, Libya.

\section{MATERIALS AND METHODS}

Fungal isolate:

$B$. cinerea was isolated from beneath the scales of the onion bulbs infected with gray mold and a pure culture was maintained on potato dextrose agar (PDA) medium for the further study.

\section{Preparation of plant extracts:}

Samples of plant leaves of Mentha longifolia L., Origanum marjoram L. and Artemisia sp L. were collected in a sterile polyethylene bags and transferred to the lab at the Department of Horticulture of the University for proper identification. Leaves were surface sterilized in $1 \%$ sodium hypochlorite solution for $3 \mathrm{~min}$. and thoroughly rinsed in sterile distilled water. Thirty grams were mashed in a sterile mortar using a sterile pestle for $3 \mathrm{~min}$. The resultant paste was soaked for $24 \mathrm{hr}$ in $100 \mu \mathrm{L}$ of water, then filtered through sterile Whatman No. 1 filter paper. The resultant extract were filtered through $0.22 \mu \mathrm{m}$ sterile filter membranes and stored at $4 \circ \mathrm{C}$ for further use.

\section{Trichoderma metabolites:}

Isolate of Trichoderma sp was grown on potato dextrose (PD) broth for 8 days, then filtered in Whatman No 1 papers and sterilized as shown above. The filtrates were used to study its effect on the growth of $B$. cinerea in vitro.

\section{Linear growth test:}

Poison plate method was followed, while different concentrations of plant extracts, and Trichoderma filtrate were obtained by amending $100 \mu \mathrm{L}$ of molten PDA with $5,10,20$ and $40 \mu \mathrm{L}$ of the different extracts. The amended medium was dispensed into sterile Petri plates and allowed to solidify. Two perpendicular lines were drawn at the bottom of each plate to cross each other at the centre of the plate. Mycelia disk (0.5 mm diameter) cut from 7 day old fungus culture was placed in center of Petri-dishes. The petri plates were sealed with parafilm and incubated at $20 \pm 2^{\circ} \mathrm{C}$ for 5 days. Control plates were treated with the same amount of sterile distilled water. The growth measured along the perpendicular lines for 3 and 5 days, and the mean growth values were obtained and then converted into the inhibition 
percentage of mycelial growth (MGI) in relation to the control treatment by using the formula, MGI $(\%)=[(\mathrm{dc}-\mathrm{dt}) / \mathrm{dc}] \times 100$, where $\mathrm{dc}$ and $\mathrm{dt}$ represent mycelial growth diameter in control and treated Petri plates, respectively.

Statistical analysis:

Four replicates of each treatment were arranged according to Completely Randomized Design (CRD), The inhibition rate was measured as described above and subjected to analysis of variance using soft ware COSTAT. Comparison of means was performed by Duncan's multiple ranges test and least significant difference (LSD).

\section{RESULTS}

The antifungal activities of Artemisia sp, M. longifolia L., O. marjoram $L$., and $T$. viride filtrate were tested against $B$. cinerea. The results of antifungal effect of the extracts of the three plant species and Trichoderma filtrate are presented in Fig. 1 and Tables 1. The effects of different concentrations of the extracts on the mycelia growth of $B$. cinerea are shown in Fig. 1. Results of this study show that all the different concentrations of the extracts presented their inhibitory effects on the growth of $B$. cinerea. The potential of these extracts to inhibit the fungal growth was differed with the different extracts, and the concentration used. On the whole, $T$. viride was more effective in inhibiting the growth of $B$. cinerea than the other used plant extracts. Data in Table 1 show that the highest concentration tested in this study was (40 $\mu \mathrm{L}$ extract: $60 \mu \mathrm{L}$ molten agar). All the tested extracts at the higher concentration inhibited the growth of $B$. cinerea. While, at low concentrations, differences began to show up among the different extracts. Trichoderma filtrate was highly effective against, $B$. cinerea as a complete inhibition of growth was observed. The inhibition occurred with $O$. marjoram was limited. The percentage of growth inhibition was varied from $36.6 \%$ at the fifth incubation day for 0 . marjoram and 40 up to $84.3 \%$ in case of Artemisia $\mathrm{sp}$. The aqueous extract of $O$. marjoram was the least effective concentration in inhibiting the growth of $B$. cinerea.

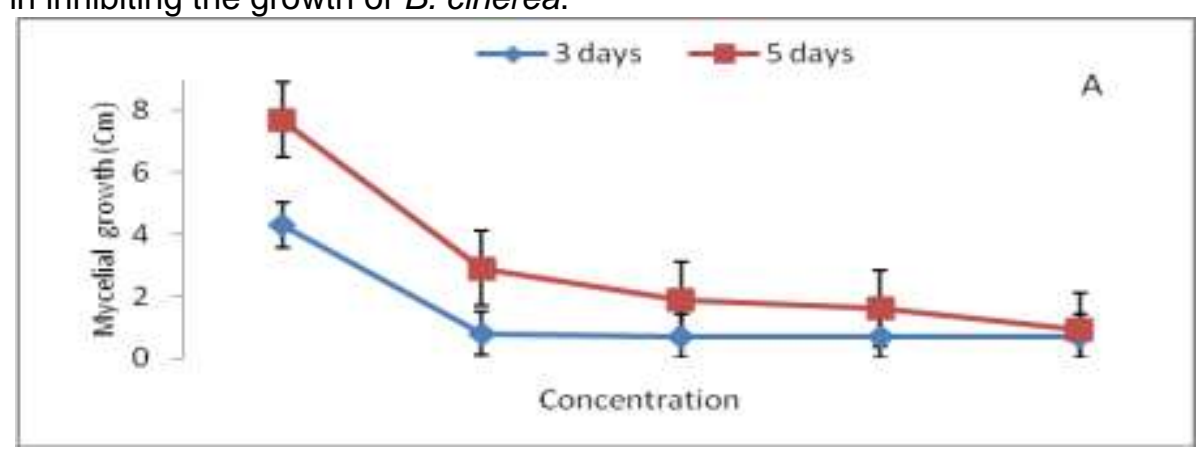


EI-Gali, Z. I. et al.

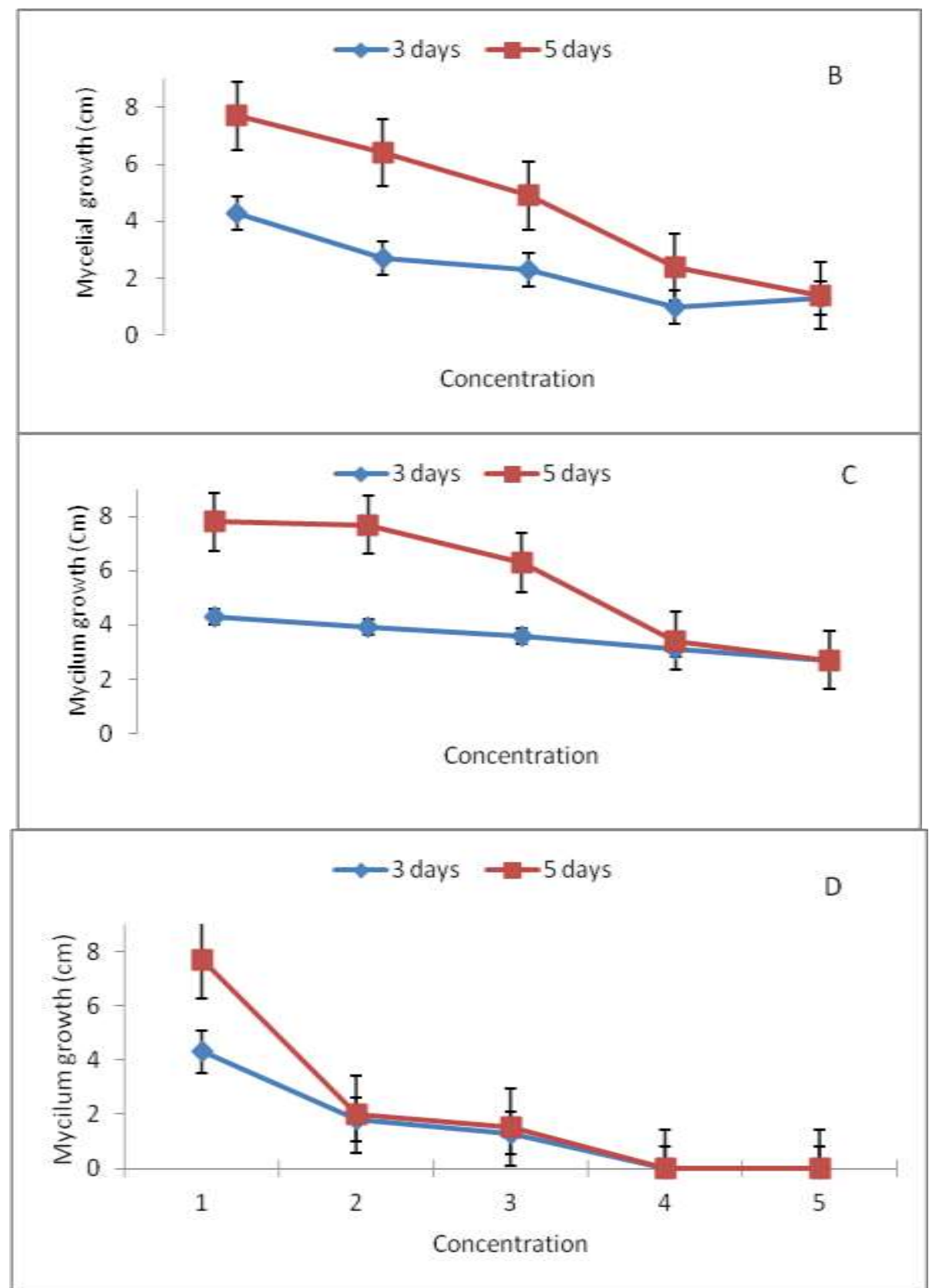

Fig. 1: Inhibition effect of some plant extracts on linear growth of Botrytis cinerea Artemisia sp, B. M. Iongifolia, C. 0. marjoram, and D. T. viride). 


\begin{tabular}{|c|c|c|c|c|c|c|c|}
\hline \multirow{2}{*}{ Plant extracts } & \multirow{2}{*}{$\begin{array}{l}\text { Days after } \\
\text { incubation }\end{array}$} & \multicolumn{5}{|c|}{ Concentration $(\mu \mathrm{L})$} & \multirow{2}{*}{ Mean } \\
\hline & & 0 & 5 & 10 & 20 & 40 & \\
\hline Artemisia sp & $\begin{array}{l}3 \\
5\end{array}$ & $\begin{array}{l}0.00 \mathrm{~b} \\
0.00 \mathrm{~d}\end{array}$ & $\begin{array}{l}81.4 \mathrm{a} \\
64.1 \mathrm{c} \\
\end{array}$ & $\begin{array}{l}84.3 \mathrm{a} \\
76.0 \mathrm{~b} \\
\end{array}$ & \begin{tabular}{|c|}
$84.3 \mathrm{a}$ \\
$79.2 \mathrm{ab}$ \\
\end{tabular} & $\begin{array}{l}86.2 \mathrm{a} \\
84.3 \mathrm{a} \\
\end{array}$ & $\begin{array}{l}67.2 \\
60.7 \\
\end{array}$ \\
\hline $\begin{array}{c}\text { Mentha } \\
\text { Iongifolia }\end{array}$ & $\begin{array}{l}3 \\
5 \\
\end{array}$ & $\begin{array}{l}00.0 \mathrm{c} \\
00.0 \mathrm{c} \\
\end{array}$ & \begin{tabular}{|l|}
$38.4 \mathrm{~b}$ \\
$17.6 \mathrm{bc}$ \\
\end{tabular} & $\begin{array}{l}47.7 \mathrm{~b} \\
38.7 \mathrm{~b} \\
\end{array}$ & \begin{tabular}{|l|}
$69.9 \mathrm{a}$ \\
$69.4 \mathrm{a}$ \\
\end{tabular} & $\begin{array}{l}82.5 \mathrm{a} \\
70.2 \mathrm{a} \\
\end{array}$ & $\begin{array}{l}47.7 \\
39.2 \\
\end{array}$ \\
\hline $\begin{array}{l}\text { Origanum } \\
\text { marjoram }\end{array}$ & $\begin{array}{l}3 \\
5\end{array}$ & $\begin{array}{l}00.0 \mathrm{~d} \\
00.0 \mathrm{~d}\end{array}$ & $\begin{array}{l}8.5 \mathrm{~cd} \\
4.4 \mathrm{~d} \\
\end{array}$ & \begin{tabular}{|l|}
$31.3 \mathrm{c}$ \\
$18.0 \mathrm{bc}$
\end{tabular} & \begin{tabular}{|l|}
$55.4 \mathrm{~b}$ \\
$29.7 \mathrm{ab}$ \\
\end{tabular} & $\begin{array}{l}66.9 \mathrm{a} \\
36.6 \mathrm{a}\end{array}$ & $\begin{array}{l}32.4 \\
17.7 \\
\end{array}$ \\
\hline $\begin{array}{c}\text { Trichoderma } \\
\text { viride }\end{array}$ & $\begin{array}{l}3 \\
5\end{array}$ & $\begin{array}{l}00.0 \mathrm{c} \\
00.0 \mathrm{c}\end{array}$ & $\begin{array}{l}48.1 \mathrm{~b} \\
41.0 \mathrm{~b}\end{array}$ & $\begin{array}{l}76.0 \mathrm{~b} \\
87.0 \mathrm{a}\end{array}$ & $\begin{array}{l}100 \mathrm{a} \\
100 \mathrm{a}\end{array}$ & $\begin{array}{r}100 \mathrm{a} \\
100 \mathrm{a}\end{array}$ & $\begin{array}{l}64.8 \\
65.6\end{array}$ \\
\hline
\end{tabular}

The numbers are means of four replicates.

Means within a row followed by the same letter are not significantly $(P<0.05)$ different based on Dancans's multiple range test.

\section{DISCUSSION}

To develop environment-friendly alternatives methods for the control of fungal plant diseases, demand on the use of plant extracts has been increased. In this study, we investigated the antifungal activities of four plant extracts versus Trichoderma filtrates against $B$. cinerea in vitro using poison plate method. Trichoderma filtrate was more effective against $B$. cinerea than the other plant extracts, these results are in agreement with the results obtained by (Sarhan, 2006). Trichoderma spp produce inhibitory substances (antibiotics and toxins) such as Emodin, Gleotoxin, Pachybasin, Trichodermin and Trichodermol which retard the growth of the pathogen (Dossantos and Dhingra, 1982), while the release of some enzymes including B- 1,3glucanase, Chitinase and Protease degrad the cell wall of the pathogen (Mehrotra, et al., 1997; Mathre, et al., 1999). It was also found that the plant extracts of $A$. arborescens, $M$. longifolia and $O$. marjoram were effective in reducing the fungal growth in vitro. However, all the extracts showed antifungal effect against $B$. cinerea. The antimicrobial effects of plant extracts depend on the kind of compound and its chemical components. More than twenty kinds of chemical compounds have been extracted from M. longifolia. The most important ones with antimicrobial activity are Menthol, Menthoforan, Menthon, Pipriton and Polgon. Additionally, it is also known that the compositions of the antimicrobial effect depends on plant species and regional condition as some research reported that there is a relationship between the composition of the extracts and the antimicrobial activity (Deans and Svoboda, 1990). Wilson et al. (1997) showed that 1,8-cineole, myrcene, a-pinene, and camphor are frequently found in different plant extracts and show that the essential oils found in Artemisia spp were associated with antifungal activities against $B$. cinerea. Similar antimicrobial activities of essential oils of $A$. annua from different countries have been previously reported against a variety of food-borne and human pathogens (Woerdenbag et al. 1993). On the other hand, In vitro studies on $B$. cinerea by using $O$. 
majorana suggests that both the plant extract and essential oil can be used for the control of this fungus.

However, this is the first study dealing with the antifungal activities of Artemisia sp, $M$. longifolia and $O$. marjoram on $B$. cinerea the causal agent of grey mold and nick rot of onion in El-Beida, Libya.

\section{REFERENCES}

Coly-Smith, J.R., Verhoff, K. and Jarvis, W.R. (1980). The Biology of Botrytis. Academic Press, London.

Deans, S. and Svoboda, K. (1990). The antimicrobial properties of marjoram (Oroganum majorana L.) volatile oil. Flavour Fragr. J. 5:187-190.

Dossantos, A.F. and Dhingra, O.D. (1982). Pathogenicity of Trichoderma spp on Sclerotinia sclerotiorum. Canadian J. of Bot., 60: 472-475.

Droby, S., Wisniewski, M.E., Cohen, L. and Weiss, B. (1997). Influence of $\mathrm{CaCl}_{2}$ on Penicillium digitatum, grapefruit peel tissue and biocontrol activity of Pichia guilliermondii. Phytopathology 87: 310-315.

Eden, M.A., Hill, R.A. and Stewart, A. (1996). Biological control of botrytis stem infection of greenhouse tomatoes. Plant Pathol. 45: 276-284.

EL-Abd, S.M. (2002). Studies on some fungal diseases infection crop in Egypt. Ph. D. Thesis Submitted to Univ. of Alexandria. Pp 204.

Ketterer, N., Fischer, B., Verhoeff, K. and Williamson, B. (1992). Biological control of Botrytis cinerea on grapevine by compost extract and their microorganisims in pure culture. Pages 179-186 in: Rec. Adv. In Botrytis Res., Proc. $10^{\text {th }}$ Int. Symp. K. Verhoeff and N.E. Malathrakis, eds. Pudoc Scientific Publishers, Wageningen, Netherlands.

Mathre, D.F., Cook, R.J. and Callar, N.W. (1999). From discovery use: Traversing the world of commercializing biocontrol agent for plant disease control. Plant Dis., 83: 972-983.

Mehrotra, R.S., Aneja, K.R. and Aggarwal, A. (1997). Fungal control agents. In: Environmentally safe approaches to crop disease control. (Rechcigl, N.A. and Rechcigl, J.E.P. 111-137) CRC Press.

Morales, M.R. and Simon, J.E. (1996) New basil selection with compact Inflorescence for the ornamental market. In: J. Jamek (ed.), progress in new crops S. ASHS press. Alexandria, VA.

Ramos, A.R, Falcao, L.L., Barbosa, G.S, Marcellino, L.H. and Gander, E.S. (2007). Neem (Azadirachta indica a. Juss) components: Candidates for the control of Crinipellis perniciosa and Phytophthora spp. Microbiological Res. 162:238-243.

Reyes, A.A.(1990). Pathogenicity, growth and sporulation of Mucor mucedo and Botrytis cinerea in cold or CA storage. Hort. Science 25:549-552.

Sarhan, A.R.T. (2006). Interaction of Horse-mint leaf extract with fungal antagonistis on some legume seed-borne fungi. Arab J. PI. Prot., 24: 118-124.

Sirjusingh, C., and Sutton, J.C. (1996). Effects of wetness duration and temperature on infection of geranium by Botrytis cinerea. Plant. Dis., 80: 160-165. 
Siva, N., Ganesan, S., Banumathy, N. and Muthuchelian (2008). Antifungal Effect of Leaf Extract of Some Medicinal Plants Against Fusarium oxysporum Causing Wilt Disease of Solanum melogena L. Ethnobotanical Leaflets 12: 156-163.

Soylu, E.M., Yigitbas, H.F., Tok, S., Soylu1, S., Kurt1, Ö., Baysal, A. and Kaya, D.(2005). Chemical composition and antifungal activity of the essential oil of Artemisia annua L. against foliar and soil-borne fungal pathogens

Staub, T. (1991) Fungicide resistance: practical experience with antiresistance strategies and the role of integrated use. Annu. Rev. Phytopathol. 29, 421-442.

Sun, O.L., Gyung, J.C., Kyoung, S. J., He, K. L., Kwang, Y. C. and Jin Cheo,I K. (2007). Antifungal Activity of Five Plant Essential Oils as Fumigant Against Postharvest and Soilborne Plant Pathogenic Fungi. Plant Pathol. J. 23(2) : 97-102.

Wilson, C. L., Solar, J. M., el Ghaout, A., Wisniewski, M. E. (1997): Rapid evaluation of plant extracts and essential oils for antifungal activity against Botrytis cinerea. Plant Dis. 81, 204-210.

Woerdenbag, H. J., Bos, R., Salomons, M. C., Hendriks, H., Pras, N., Malingre, T. M. (1993): Volatile constituents of Artemisia annua L. (Asteraceae). Flav. Fragr. J. 8, 131-137.

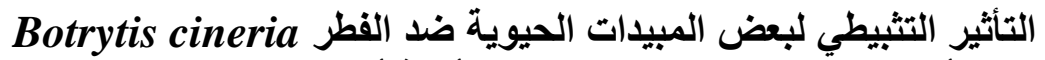

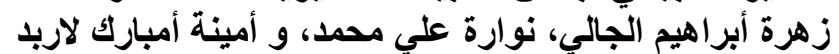

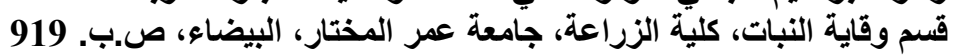 بريد إلكتروني: Z_Elgali@yahoo.com}

استهدفت هذه الدراسة تقييم فعالية التأثير التثبيطي لأربعة من المبيدات الحيوية والمتمثلة

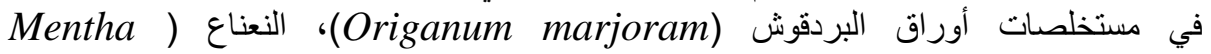
(Artemisia sp.) (الثرش (longifolia

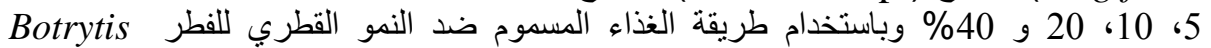
cinerea

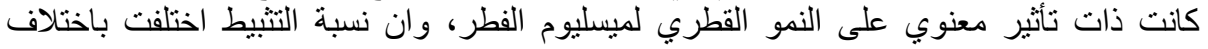

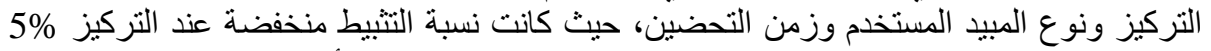

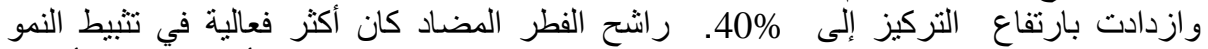

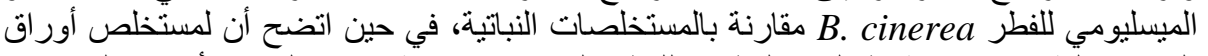

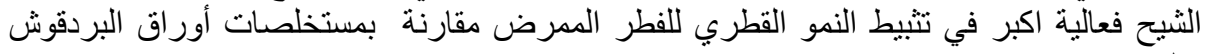
و النعناع. كلمات مفتاحية: مضادات فطرية، مستخلصات نباتية، فطريات مضادة، Botrytis cinerea.

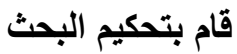

كلية الزراعة - جامعة المنصورة

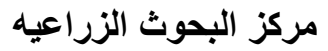

أ. أد / محمد عبد البحث الرحمن الوكيل

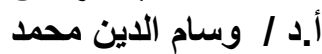

